\title{
Android service to interface mosquitto messaging broker (MQTT)
}

Fecha de recepción: 2021-12-26 • Fecha de aceptación: 2022-01-05 • Fecha de publicación: 2022-02-10

Cristian Mauricio Gallardo Paredes ${ }^{1}$

Universidad Politécnica de Tomsk, Rusia

kristianmaurisio1@tpu.ru

https://orcid.org/0000-0002-5361-9144

Patricia del Rocío Rodríguez Fiallos ${ }^{2}$

Ministerio de Educación Distrito 18D02, Ecuador

patriciad.rodriguez@educacion.gob.ec

https://orcid.org/0000-0002-5213-1008

Francisco Javier Galora Silva ${ }^{3}$

Universidad Internacional de la Rioja, Ecuador francisco.galora049@comunidadunir.net https://orcid.org/0000-0002-5464-5336

\begin{abstract}
Real-time messages are used at a high level by different computer applications, there are different servers, protocols, etc. that can be used and are available on the Internet, however, these are created in such a way that the consumption of computational resources is very high and would only be optimal if we use a server with great features. This research work aims to develop a service on Android service to interface mosquitto messaging broker (MQTT) and provide a suitable mechanism to receive requests from an Android application at the same time also notify that some data has arrived, data are stored in the SQLite manager, which uses few computational resources and is suitable for small applications, which are testing protocols and messaging servers. The experimental results show that the service meets the initial objectives of the work, allowing to create of a messaging system based on publishers and subscribers for the Android platform.
\end{abstract}




\section{KEYWORDS: service, android, Mosquito, MQTT}

\section{RESUMEN}

Los mensajes en tiempo real son utilizados en un alto nivel por diferentes aplicaciones informáticas, existen diferentes servidores, protocolos, etc., que se pueden utilizar y están disponibles en Internet; sin embargo, estos están creados de tal manera que el consumo de recursos computacionales es muy elevado y solo sería óptimo si se utiliza un servidor con grandes prestaciones. Este trabajo de investigación tiene como objetivo desarrollar un servicio sobre Android, que sirva de interfaz con el broker de mensajería Mosquitto (MQTT) que proporcione un mecanismo adecuado para recibir peticiones de una aplicación Android y al mismo tiempo también notifique que han llegado unos datos, mismo que se almacenan en el gestor SQLITE, que utiliza pocos recursos computacionales y es adecuado para pequeñas aplicaciones, que están probando protocolos y servidores de mensajería. Los resultados experimentales muestran que el servicio cumple con los objetivos iniciales del trabajo, permitiendo crear un sistema de mensajería basado en editores y suscriptores para la plataforma Android.

\section{PALABRAS CLAVE: servicio, Android, Mosquito, MQTT}




\section{Introduction}

With the notoriety of cell phones, individuals are progressively subject to their cell phones to receive continuous messages, so texting is especially significant (Zhang et al., 2007). As of now, we can sidestep the transporters, through a standard TCP/IP organization to send messages straightforwardly to the cell phone (Peiji \& Yanai, 2001).

It's obviously true that over the most recent couple of years, cell phones have altered the entire world, and a piece of this significant world pattern has involved changing the manner in which individuals speak with each other; one of the components of this current has been texting administration. The push message administrations were executed different convention structures like XMPP, CoAP, and MQTT. These different conventions are utilized for each unique circumstance, specifically the MQTT convention was intended to chip away at low-power gadgets pleasantly as a lightweight convention and has been utilized in numerous loT gadgets and texting frameworks (Hwang et al., 2016).

MQTT protocol become our best option due for its undeniable potential benefits. It is an open, basic, lightweight, and simple to-carry out informing convention. At first, it was intended to associate huge quantities of far-off sensors and control gadgets (Silva et al., 2017). The convention has been applied in an assortment of inserted frameworks. Clinics utilize this convention to speak with pacemakers and other clinical gear providers. Oil and gas organizations use it to screen oil pipelines large number of miles away (Shaoyue et al., 2012).

A portable application that utilizes MQTT sends and gets messages by calling a MQTT library. Messages are traded through a MQTT informing server. The MQTT customer and server handle the intricacies of conveying messages dependably to the versatile application and monitor the cost of organization the board.

MQTT applications run on cell phones, for example, cell phones and tablets. MQTT is likewise utilized in telemetry to get information from sensors and to control them from a distance. For cell phones and sensors, MQTT offers a profoundly adaptable distribution/membership convention with secure conveyance.

A few review papers are tending to various attributes of distribute/buy in based frameworks, like plan, execution, quality necessities, directing calculations, and so forth In "Nature of Administration in Wide-Scale Distribute Buy in Frameworks", the creators research the cutting edge modern and scholarly distribute/buy in arrangements zeroing in on adaptability and quality prerequisites, while in "The Many Essences of Distribute/Buy in", the creators present order dependent on correspondence, different distribute/buy in plans, plan, and executions, yet as far as we could possibly know, there is no overview which recognizes key-necessities for loT distribute/buy in arrangements.

The following research is also carried out in this important area, such as:

\section{A. Design and implementation of a reliable message transmission system based on}




\section{MQTT protocol in IoT}

This paper planned and executed a dependable message transmission framework utilizing MQTT convention to keep up with requesting between messages for the workplace. This (framework) comprises of MQTT convention, solid message transmission server, and customer module (Hwang et al., 2016).

B. Design and implementation of push notification system based on the MQTT protocol

This paper depicted a technique for pushing warning framework dependent on the MQTT convention. It tends to be utilized to tackle the issue of moment pushing different messages from the server to the versatile customer (Tang et al., 2013).

\section{System of acquisition, transmission, storage and visualization of pulse oximeter and ECG data using android and MQTT}

The creators present an arrangement of wellbeing information assortment, transmission, and capacity intended for electrocardiography (ECG) and Heartbeat Oximetry results, the objective is to address this test by making a framework for gaining and communicating information through Bluetooth to an Android versatile stage, which sends it to a distant server, where the information is put away in a data set and opens up for perception. This empowers any far off client to get to imperative information on a patient without being actually present (Barata et al., 20139.

\section{Correlation analysis of MQTT loss and delay according to QoS level}

This examination breaks down the MQTT message transmission process which comprises of truly wired/remote distribute customer, specialist server, and buy in customer. By communicating messages through 3 degrees of QoS with different sizes of payloads, we have caught parcels to examine start to finish deferrals and message misfortune (Lee et al., 2013).

All these papers are of great help as a base for the realization of this project, because they allow understanding the benefits that can be obtained when using mosquito MQTT and its linkage with other technologies that would greatly benefit people, this can be evidenced by the investigations carried out in this important area.

The purpose of this research is to perform an android service to interface Mosquitto Message Broker (MQTT), offering a suitable mechanism to receive requests from Android applications and also to notify that some data has arrived.

\section{Methodology}

In this chapter, we propose a method for sending and receiving messages, this is done through an android service, which allows you to create the topic, make subscriptions, perform publication, 
display all messages. For the experiment, we used Linux-based Debian 8 for the server and an open-source project Mosquitto MQTT for Broker server software.

It is very important to keep the guarantee of sending messages reliably, the service developed in Android through the mobile application communicates with other loT devices messages must have atomicity, consistency, and performance (Schiper \& Raynal, 1996). In addition, the mobile application for reliable message transmission should be able to view the previous messages for reliable message transmission or communication history.

The definition of all components of both software and hardware the existing relationships between them are the most relevant aspects at the time of execution of a project. Next, all the architecture adjacent to this project will be described and specified.

\subsection{MQTT service architecture}

The service is within the mobile application, the service uses MQTT libraries to perform the functions of: Connect, Disconnect Publish, subscribe, QoS. By executing a .sh file the messages are stored in an SQLite database (see Figure 1).

Figure 1.

Service Architecture

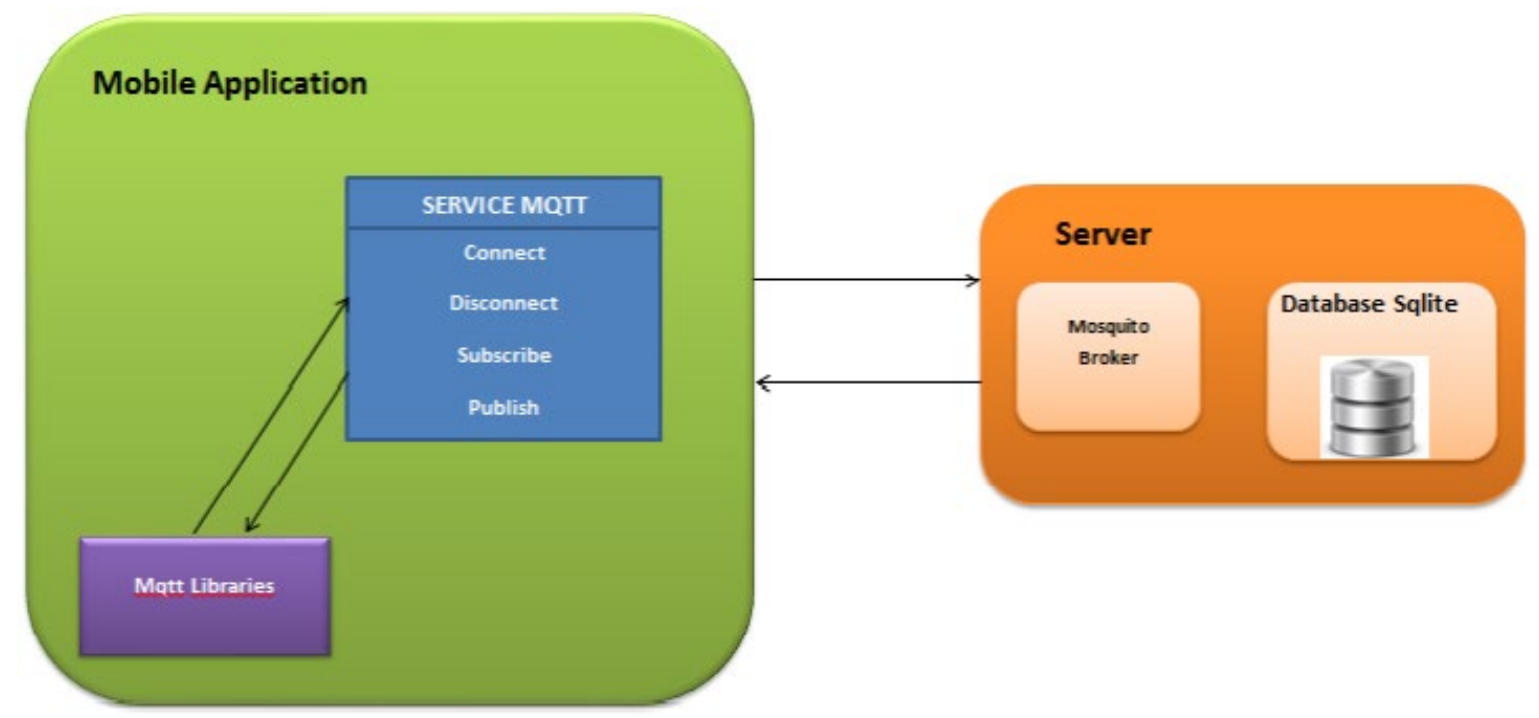

The central node that goes about as a server or representative, equipped for working up to 500000 messages. It is the merchant definitively the component responsible for dealing with the organization and sending the messages. Correspondence dependent on themes, the customer distributes the message, makes and the hubs that wish to get it should prefer it. The intermediary server associates with a SQLite information base utilizing a clump cycle to store the messages coming from the Distributers, MQTT customers preferred a point. 


\subsection{Architecture of MQTT message transmission between multiple clients}

Customers under remote organization climate were tried under Android climate. The remote climate can be viewed as reasonable, since the correspondence from portable climate goes through $3 G$ organization and arrives at specialist waiter (see Figure 2).

Figure 2.

The general architecture of MQTT message transmission between multiple clients

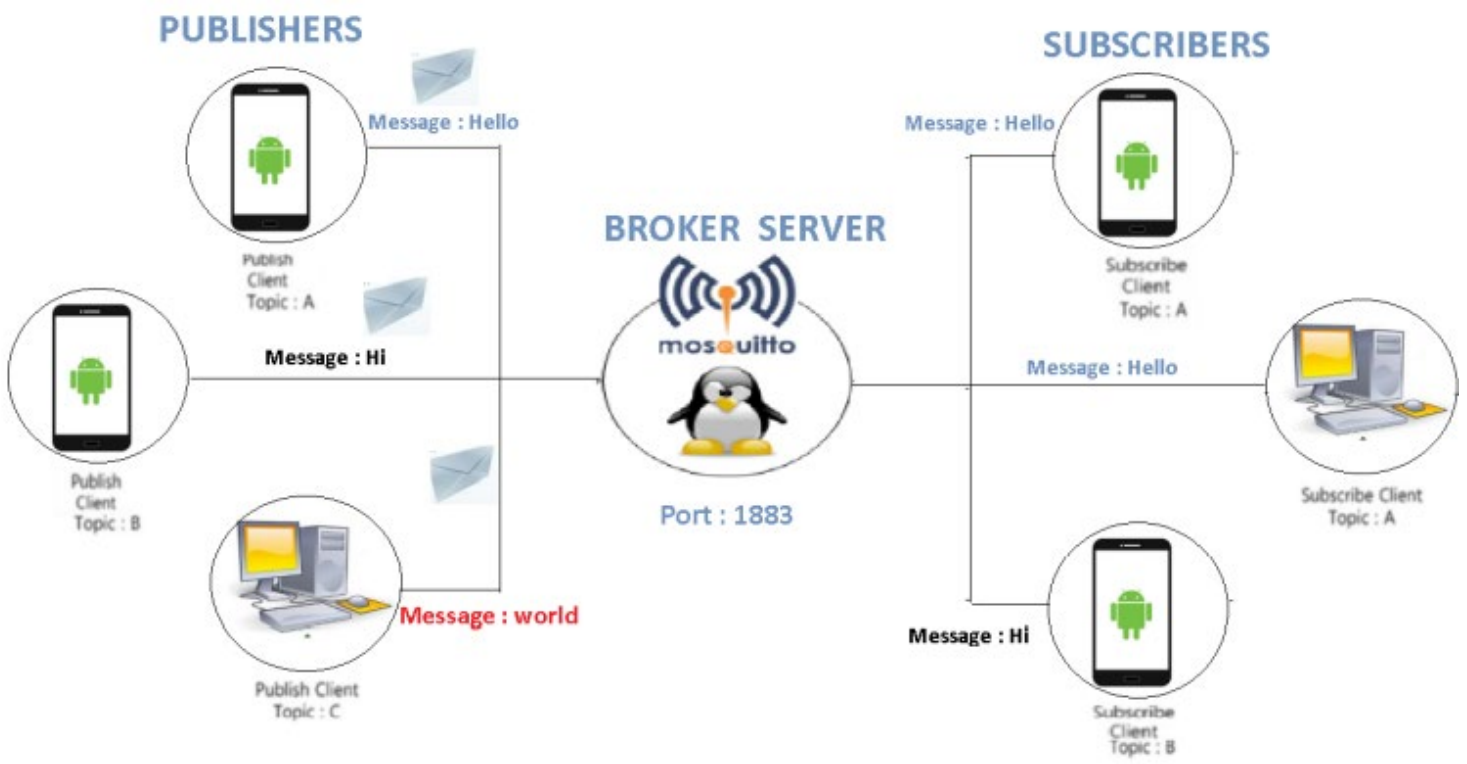

It investigates message misfortune and start to finish delay by gathering bundles among customer and server during the 5 minutes' estimation. With regards to start to finish delay, we use timestamps shaped as bundles move from the membership server to distribute the customer through the representative server. The retransmission demand bundles were counted when of five minutes to gauge message misfortune.

\subsection{Implementation}

In the first place, performed standard tests to comprehend the MQTT standards with online test agents (test.mosquitto.org, broker.mqttdashboard.com) and the order line: preferring points and distributing messages in those subjects. From that point onward, research was done to assess what was at that point made with respect to Java.

MQTT customers to characterize a beginning stage. We ran over various programming like Java customer Application Programming Points of interaction (APIs) and dealers, which are recorded in Table 1. 
Table 1.

Implementation features

\begin{tabular}{lll}
\hline Brokers & License & Java Client APIS \\
\hline Active MQ & Open-source & $\begin{array}{l}\text { Eclipse Paho - a Java client } \\
\text { developed by the Eclipse }\end{array}$ \\
& & Foundation (lyer et al., 2018) \\
\hline Hive MQ & Commercial & $\begin{array}{l}\text { MQTT-client - a Fuse source } \\
\text { Java MQTT client with a variety } \\
\text { of API styles (Manh Pham et al., } \\
\text { 2019) }\end{array}$ \\
\hline IBM WebSphere Message & Commercial & IBM WebSphere MQ Telemetry \\
broker & & $\begin{array}{l}\text { provides a Java client API } \\
\text { (Katsikeas et al., 2017) }\end{array}$ \\
\hline Mosquito & Free \\
\hline
\end{tabular}

\subsubsection{Local Server MQTT}

First import the repository package signing key:

- wget http://repo.mosquitto.org/debian/mosquitto-repo.gpg.key

- sudo apt-key add mosquitto-repo.gpg.key

Then make the repository available to apt:

- cd /etc/apt/sources.list.d/

Then one of the following, depending on which version of Debian

- sudo wget http://repo.mosquitto.org/debian/mosquitto-wheezy.listsudo

- wget http://repo.mosquitto.org/debian/mosquitto-jessie.list

Update and install mosquitto

- apt-get update 2. apt-get install mosquitto

Run mosquito and see the status

- Mosquitto -c /etc/mosquitto/mosquitto.conf 2. Service mosquitto status

Create service on android studio, see Figure 3. 
Figure 3.

Service on Android Studio

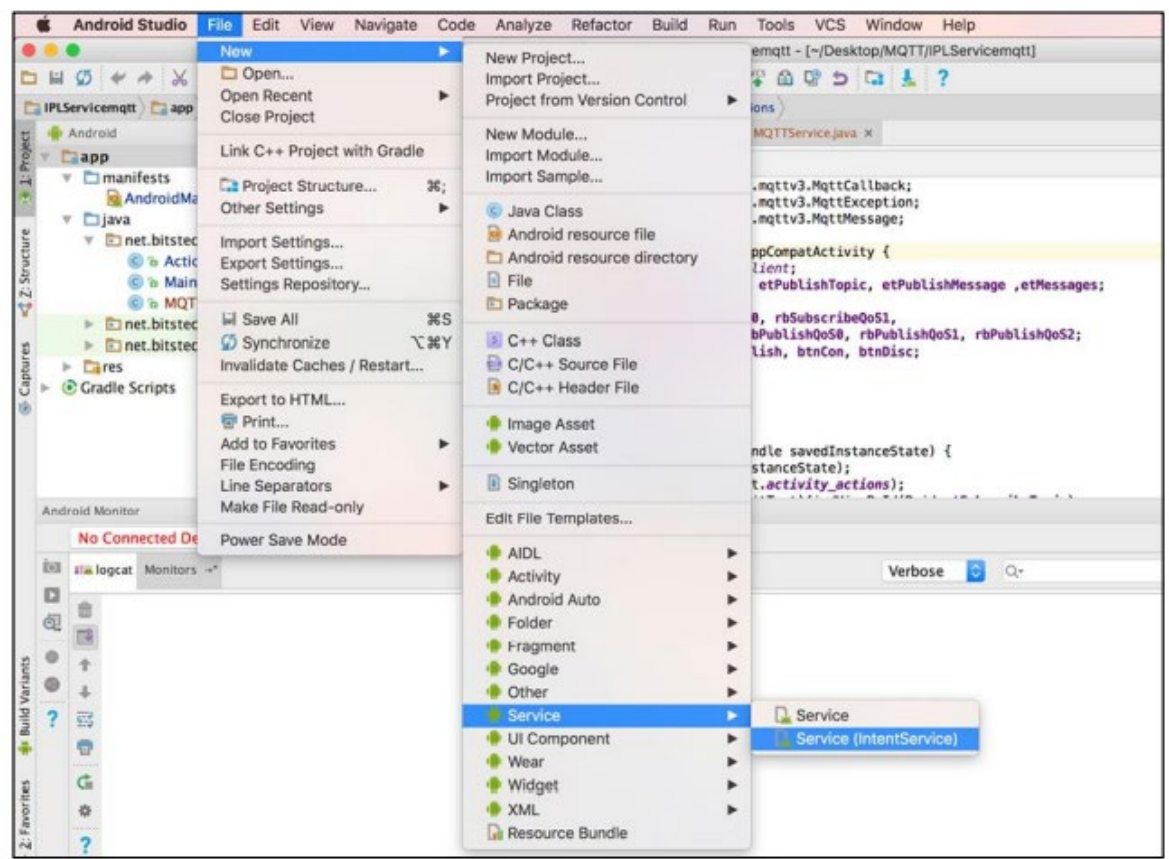

\subsubsection{Message storage SQLite}

Before configuring the MQTT server you need a requirement to have installed an Ubuntu or Debian server, with a non-root, sudo-enabled user and basic firewall.

Installing SQLite (Nemetz et al., 2018)

- sudo apt-get update;

- sudo apt-get install sqlite3 libsqlite3-de

Create a database, if you are still in the sqlite3 program, exit with. Quit in the SQLite flag, then run the command:

- sqlite3 \$HOME/MESSAGE.DB

Creating tables corresponding to each QoS (see Figure 4).

- sqlite3 \$HOME/MESSAGE.DB "CREATE TABLE messagesQOSO(id_message INT ,message VARCHAR(200), topic VARCHAR(50), date text);";

- sqlite3 \$HOME/MESSAGE.DB "CREATE TABLE messagesQOS1(id_message INT ,message VARCHAR(200), topic VARCHAR(50), date text);"; 
- sqlite3 \$HOME/MESSAGE.DB "CREATE TABLE messagesQOS2(id_message INT ,message $\operatorname{VARCHAR}(200)$, topic $\operatorname{VARCHAR}(50)$, date text);";

Figure 4.

Message database

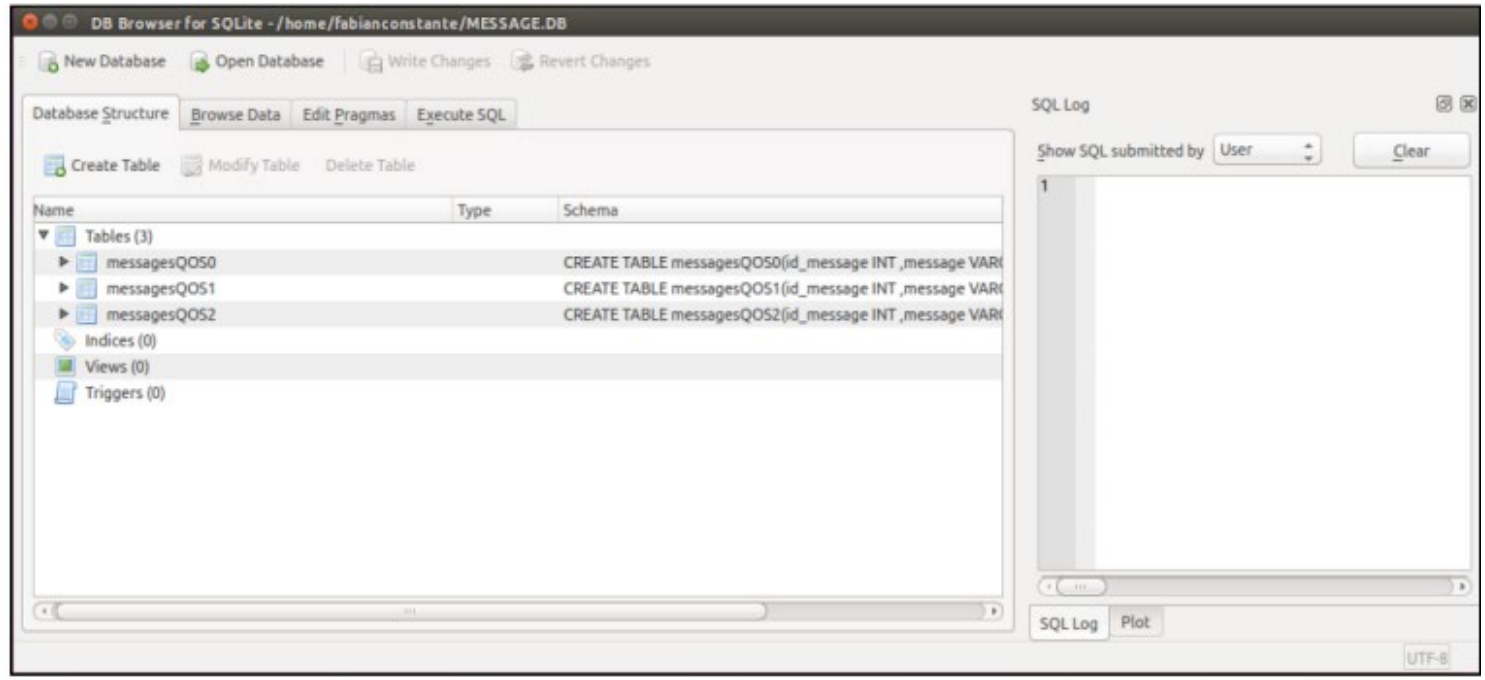

\section{Results}

\subsection{Functional testing}

Functional testing is a quality confirmation (QA) process and a kind of discovery testing that puts together its experiments with respect to the details of the product part under test. Capacities are tried by taking care of them input and inspecting the result, and inward program structure is seldom thought of (dissimilar to white-box testing). Table 2, portrays exhaustively the particular of the tests that are performed for usefulness

Table 2. 
Usefulness test

\begin{tabular}{|c|c|c|c|}
\hline Case & $\begin{array}{l}\text { Event } \\
\text { number }\end{array}$ & Test & Result \\
\hline \multirow{2}{*}{$\begin{array}{l}\text { 1. Connecting } \\
\text { the Client to the } \\
\text { MQTT Server }\end{array}$} & 1 & $\begin{array}{l}\text { The client specifies the IP address } \\
\text { of the host message broker and the } \\
\text { port number assigned by MQTT to } \\
\text { verify the status of the connection. }\end{array}$ & $\begin{array}{l}\text { The connection to } \\
\text { the MQTT server is } \\
\text { successful. }\end{array}$ \\
\hline & 2 & $\begin{array}{l}\text { Display the successful connection } \\
\text { message to the server }\end{array}$ & $\begin{array}{l}\text { The displayed } \\
\text { message indicates } \\
\text { that the connection is } \\
\text { successful. }\end{array}$ \\
\hline \multirow{2}{*}{$\begin{array}{l}\text { 2. Subscription } \\
\text { to a topic and } \\
\text { QoS }\end{array}$} & 1 & $\begin{array}{l}\text { In the Android app, the subscription } \\
\text { parameter and the quality parameter } \\
\text { are sent, to press the "Subscribe" }\end{array}$ & $\begin{array}{l}\text { Successful subscription } \\
\text { to a topic }\end{array}$ \\
\hline & 2 & $\begin{array}{l}\text { Display message indicating } \\
\text { subscription to the topic }\end{array}$ & $\begin{array}{l}\text { The message indicates } \\
\text { successful subscription }\end{array}$ \\
\hline \multirow{2}{*}{$\begin{array}{l}\text { 3. Message } \\
\text { publishing and } \\
\text { QoS }\end{array}$} & 1 & $\begin{array}{l}\text { Enter the channel where the user } \\
\text { has subscribed, write any message } \\
\text { and press the "Publish" button, verify } \\
\text { that the published message has } \\
\text { been sent to the server. }\end{array}$ & $\begin{array}{l}\text { The MQTT server } \\
\text { displays the received } \\
\text { message }\end{array}$ \\
\hline & 2 & $\begin{array}{l}\text { From the server send a reply } \\
\text { message indicating that the message } \\
\text { has been successfully published }\end{array}$ & $\begin{array}{l}\text { The message indicates } \\
\text { that data has been } \\
\text { successfully published }\end{array}$ \\
\hline $\begin{array}{l}\text { 4. Storing sent } \\
\text { messages in a } \\
\text { database }\end{array}$ & 1 & $\begin{array}{l}\text { All messages sent in each QoS from } \\
\text { different clients will be stored }\end{array}$ & $\begin{array}{l}\text { Qo0 and Qo1 May } \\
\text { have lost messages } \\
\text { Qo2 This level has no } \\
\text { loss in sent messages }\end{array}$ \\
\hline
\end{tabular}

1. Connecting the client to the MQTT Server. The connection to the server from the application through the service was satisfactory (see Figure 5).

Figure 5. 
Connecting the Client to the MQTT Server
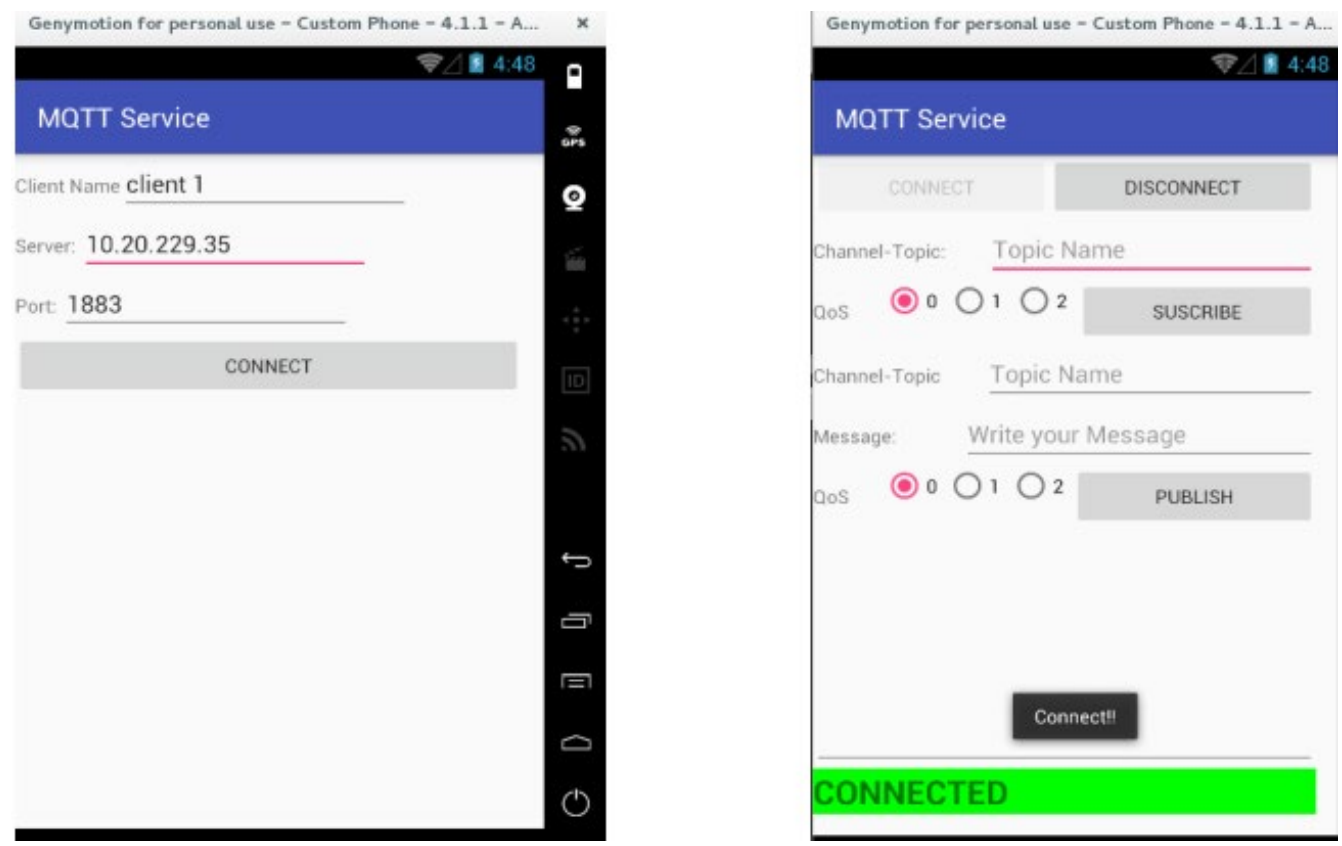

2. Subscription to a topic and QoS. - The subscription to a topic was satisfactory, this is sow in Figure 6.

Figure 6.

Subscription Interface to the topic

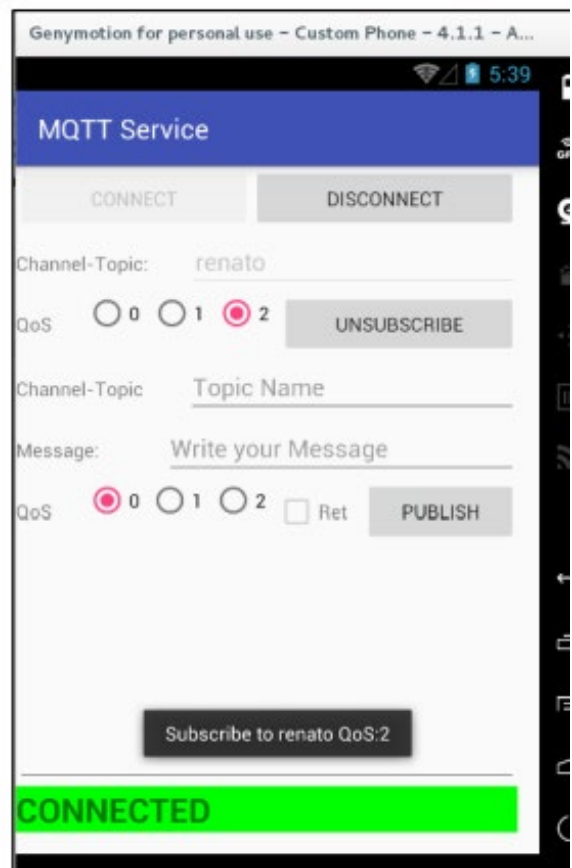


3. Message publishing and QoS. Messages publishing on a topic was satisfactory, see Figure 7.

Figure 7.

Publication of an MQTT message

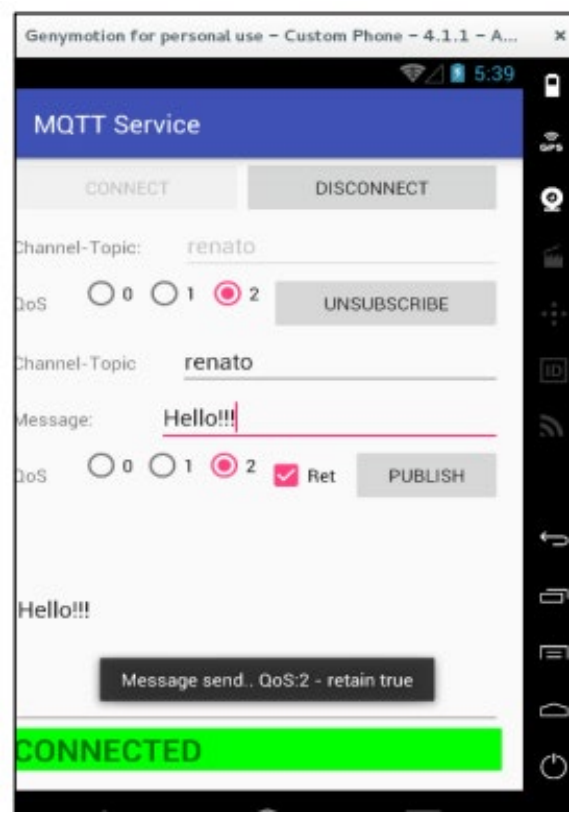

4. Storing sent messages in a database. - The user submits, the message is automatically stored in a SQLite Database, this is possible when the .sh program is running. As shown in Figure 8.

Figure 8.

Storage of messages sent through the MQTT Service

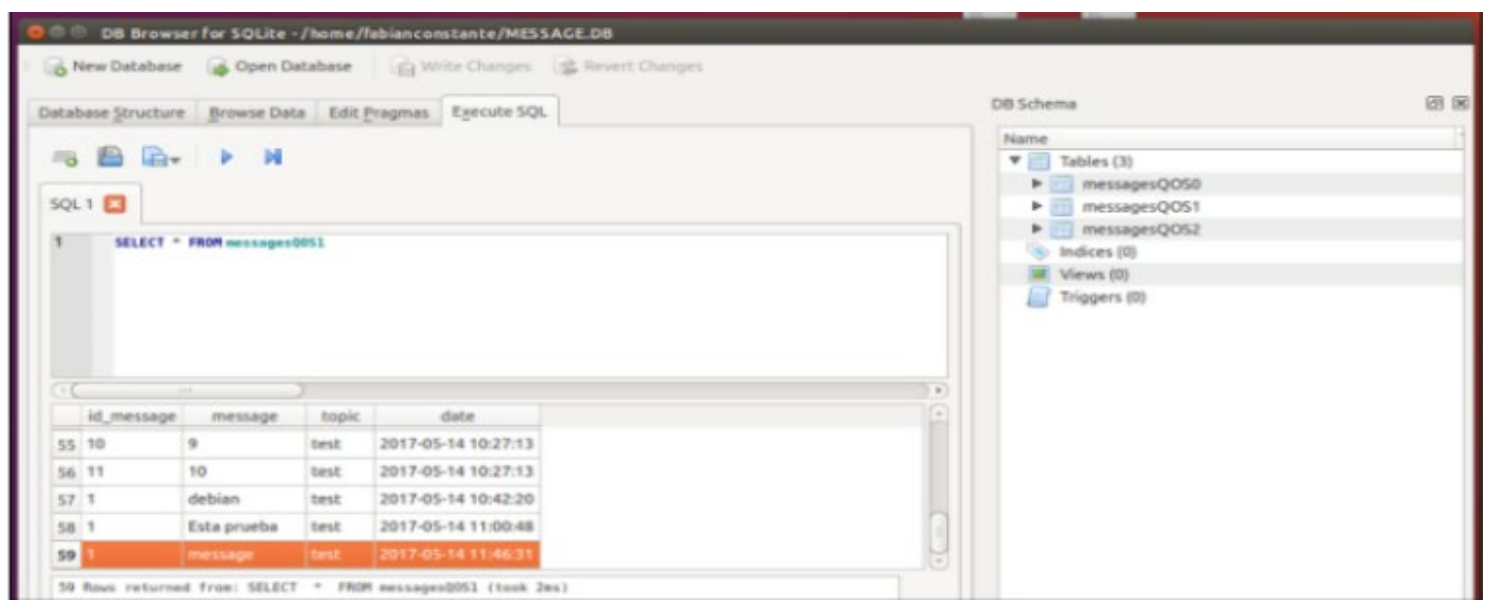

\section{Conclusions}


Can be assured that MQTT is the protocol has used to provide new and revolutionary performance, it opens new areas for messaging use cases. As MQTT specializes in low-bandwidth, high-latency environments, it is considered an ideal protocol for machine-to-machine (M2M) communication.

We specified the design of a pushing notification system and discussed details of key techniques that make the system effective and easy to maintain. This message push system is based on MQTT protocol and makes it possible to push messages to clients in real-time.

From the functionality tests, positive results were obtained, users connected and sent messages correctly and quickly, this on a local server. While in the performance tests it was verified that in QoS1 a message was lost and the reception of the messages with the levels QoS0 and QoS2 were successful. This ensures that messages arrive correctly to users. 


\section{References}

Barata, D., Louzada, G., Carreiro, A., \& Damasceno, A. (2013). System of acquisition, transmission, storage and visualization of Pulse Oximeter and ECG data using Android and MQTT. Procedia Technology, 9, 12651272.

Hwang, H. C., Park, J., \& Shon, J. G. (2016). Design and implementation of a reliable message transmission system based on MQTT protocol in IoT. Wireless Personal Communications, 91(4), 1765-1777.

lyer, S., Bansod, G. v., Praveen Naidu, V., \& Garg, S. (2018). Implementation and Evaluation of Lightweight Ciphers in MQTT Environment. 3rd International Conference on Electrical, Electronics, Communication, Computer Technologies, and Optimization Techniques, ICEECCOT 2018, 276-281. https://doi.org/10.1109/ ICEECCOT43722.2018.9001599

Katsikeas, S., Fysarakis, K., Miaoudakis, A., Van Bemten, A., Askoxylakis, I., Papaefstathiou, I., \& Plemenos, A. (2017). Lightweight \& secure industrial loT communications via the MQ telemetry transport protocol. In 2017 IEEE Symposium on Computers and Communications (ISCC) (pp. 1193-1200).

\section{https://doi.org/10.1109/ISCC.2017.8024687}

Lee, S., Kim, H., Hong, D. K., \& Ju, H. (2013). Correlation analysis of MQTT loss and delay according to QoS level. In The International Conference on Information Networking 2013 (ICOIN) (pp. 714-717).

Manh Pham, L., Nguyen, T.-T., \& Tran, M.-D. (2019). A Benchmarking Tool for Elastic MQTT Brokers in loT Applications. International Journal of Information and Communication Sciences, 4(4), 59. https://doi.org/10.11648/J.IJICS.20190404.11

Nemetz, S., Schmitt, S., \& Freiling, F. (2018). A standardized corpus for SQLite database forensics. Digital Investigation, 24, S121-S130. https://doi.org/10.1016/J.DIIN.2018.01.015

Peiji, L, \& Yanai, W. (2001). The Application of Push Technology in Mobile Internet Communications World, 31, pp. $31-32$.

Schiper, A., \& Raynal, M. (1996). From group communication to transactions in distributed systems. Communications of the ACM, 39(4), 84-87. https://dl.acm.org/doi/abs/10.1145/227210.227230

Shaoyue, H., Xiaodong, X., \& Zuyuan, M. (2012). The Application of Active Push Technology in Mobile Collaboration Education [J]. Modern Education Technology, 4, 100-103.

Silva, C., Toasa, R., Martinez, H. D., Veloz, J., \& Gallardo, C. (2017). Secure push notification service based on MQTT protocol for mobile platforms. In XII Jornadas Iberoamericanas de Ingeniería de Software e Ingeniería del Conocimiento y Congreso Ecuatoriano en Ingeniería de Software (pp. 69-84). 
Tang, K., Wang, Y., Liu, H., Sheng, Y., Wang, X., \& Wei, Z. (2013). Design and implementation of push notification system based on the MQTT protocol. In International Conference on Information Science and Computer Applications (ISCA 2013) (pp. 116-119). Atlantis Press.

Zhang, W. M., Zhang, M., Bi, J., \& Qin, Z. (2007). Instant messaging: The present and the future. MINIMICRO SYSTEMS-SHENYANG-, 28(7), 1162-1168. https://en.cnki.com.cn/Article en/CJFDTotal-XXWX200707001. htm 
Copyright (c) 2022 Cristian Mauricio Gallardo Paredes, Patricia del Rocío Rodríguez Fiallos y Francisco Javier Galora Silva

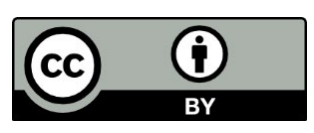

Este texto está protegido bajo una licencia internacional Creative Commons 4.0.

Usted es libre para Compartir-copiar y redistribuir el material en cualquier medio o formato - y Adaptar el documento - remezclar, transformar y crear a partir del material-para cualquier propósito, incluso para fines comerciales, siempre que cumpla las condiciones de Atribución. Usted debe dar crédito a la obra original de manera adecuada, proporcionar un enlace a la licencia, e indicar si se han realizado cambios. Puede hacerlo en cualquier forma razonable, pero no de forma tal que sugiera que tiene el apoyo del licenciante o lo recibe por el uso que hace de la obra.

\section{$\underline{\text { Resumen de licencia - Texto completo de la licencia }}$}

